\title{
Nexus Between Marketing of Financial Services and Banks' Profitability in Nigeria: Study of United Bank for Africa Plc (Uba)
}

\author{
BABAJIDE, D. Adesina ${ }^{1 *}$ ODUWOLE, Wahid Kolawole ${ }^{2} \quad$ TAIWO, Adebola Samuel ${ }^{3}$ \\ 1.Department of Banking and Finance, School of Management and Business Studies, Yaba College Technology \\ 2.Department of Marketing, School of Management and Business Studies, Yaba College Technology \\ 3.Department of Business Administration and Management, D.S. Adegbenro ICT Polytechnic, Itori Ewekoro. \\ Ogun State
}

\begin{abstract}
Customer are the centerpiece of any business, but for a longtime, Nigerian banks had operated in the sellers' market, the situation has changed in line with development within and outside the country which made Nigerian banks to appreciate the need to put the customer at the center of their activities. Banks are endowed with the ability to efficient allocate financial resources hence banks adopt marketing tool for survival with introduction varieties of new product modified to fit into the customers' need. The specifically, this paper analyses the relationship between marketing of banking service and bank profitability.Data were sourced from primary source of data collection making use of questionnaire. Samples were drawn from United Bank for Africa branches in Badagry, Alaba, Egbeda and Ikeja all in Lagos. The respondents were made up of 100 staff and customers. Data collected were analyzed using non parametric statistical tool of Chi-Square $\left(X^{2}\right)$. It was discovered that majority of respondents agree that they were encouraged to open an account due to sales promotion by the bank and the advertisement. It was established that marketing of banking services has correlation to profitability of the industry in Nigeria and that marketing strategies employed has improved the performance of banking sector in Nigeria. It was recommend that banking organization should employ more of promotional activities to capture the market areas that are yet to be reached and engage broader marketing planning concepts because of the increasing market opportunities.
\end{abstract}

Keywords: Bank Performance, Bank Efficiency, Bank Productivity

DOI: $10.7176 /$ RJFA/10-24-10

Publication date: December $31^{\text {st }} 2019$

\section{Section I: Background of Study}

The role of financial sector in economic growth has been well recognized in the development literature and has been the subject of great debate amongst economists of both old and new (Ikpefan, 2013). Banks in major economies of the world are the nerve centre of the economy, their function cut across all sector of the economy. It is an institution endowed with the ability of money creation, provision of effective payment system, and efficient allocation of financial resources (Alford, 2011). It also serves as available channel through which government monetary and credit policies are implemented. Becker, Chammard, Hussein, Kotsuji, and Quagraine (2008) posited that banks and other financial institutions (Insurance companies, Finance houses, bureau de change) and the regulatory authorities (Central Bank of Nigeria, National Deposit Commission, Securities and Exchange Commission and National Insurance Commission) make up the financial system of the country. Mohan and Kotler (2008) observed that only countries with high per capita incomes can experience rapid growth in financial assets. Levine et al. (2000) enumerated the composition of financial assets as follows; bank credit which includes credit to private and credit to the public sectors, and stock market developments which include all instruments, long run or short run that are traded in the stock markets. Only when such financial assets are identified with a country will such country be able to approximate financial deepening/development adequately. Financial resources are mobilized from surplus economic units and channeled to economic activities or deficit economic units by financial institutions. In doing this, they evolve appropriate structures necessary for the intermediation functions which they perform (Nzotta \& Okereke, 2009). Various studies have shown that there is a strong and positive relationship between the financial sector and economic growth and development. Michael (2016) shows that the level of financial institution development is the best indicator of general economic development. Goldman (2009) contends that financial institution development is of prime importance for real development because the financial superstructure in the form of both primary and secondary securities accelerates economic growth and improves economic performance to the extent that it facilitates the migration of funds to the best users.

It was established that low level of the financial superstructure affects economic development negatively. Hence lack of financial institutions in developing countries is an indication of lack of demand for their services. Patrick, (2016) observed that establishment and the expansion of financial institutions in an economy promote growth, and terms this - supply leading phenomenon or financial-led' growth hypothesis This latter view has been popular among governments in developing countries as a means to promoting economic growth and 
development (Habibullah and Eng, 2006).

The place of marketing in any business organization cannot be underestimated in the banking industry it has successfully occupied a dominant position in the banking sector in view of the recent dwindling performance of the sector. Banks now adopt marketing as a tool for survival; varieties of new product are also modified to reflect the need and wants of the numerous dynamic customers. Ability of any bank to survive the present level of competition now hinges on aggressive marketing strategies. The United States of America Chartered Institute of Marketing define marketing as the management process responsible for identifying, anticipating and satisfying customer requirement profitably. Marketing process is predicated on exchange relationship that is mutually beneficial to both the customer obtain satisfaction from the goods and services produced by the seller in exchange for the value given to the seller by the borrower. Marketing can be defined among other as a process, that is the societal goals and aspirations attempt to establish a mutually satisfying exchange relationship between people and organization, which seek to satisfy their requirement.

Daniel and Wandera (2013) noted that marketing play a vital role to emerging economies where most borrowers have no access to capital markets. Thus, they are considered as an intermediary between the depositors and borrowers. According to Rawlin et al. (2012), the principal aim of any business is to make profits. That is why any asset created in conveyance of business should generate income for the business. Since this issue is applicable for the banking sector business, banks should give due consideration on the management of loans because lending is the main business of commercial banks and loan is normally the main assets and vital source of revenue for the commercial banks (Daniel and Wandera, 2013). Therefore, banks do grant loans and advances to individuals, business organizations as well as government in order to enable them operates on investment and development activities as a mean of contributing toward the economic growth of a country in general and aiding their growth in particular.

\subsection{Statement of Problem}

Economic reforms have been the order of day in the economic growth of the developing country which culminates in banks reforms that compelling banks to raise their capital base since then the banks that emerged has been striving to justify the need for recapitalization. For any banks to stay afloat now effective promotion and marketing of financial services is very crucial since their services are intangible products, and it is hard to stand out, considering the fact that all banks offer similar products. These services are seldom unique and they are easy for competitors to copy. Also, many people cannot make a distinction between different banks' services, and they are often not aware of the wide range of different financial services available to them.

Marketing and promotion of financial services is an understudied area in banking industry. Much of the bank marketing literature has concentrated on marketing theory more than promotional practices. Unfortunately, the issues of marketing are becoming more complicated owing to the increasing competition in the banking sector, which is largely due to the global financial recessions as well as the banking reforms of the Central Bank of Nigeria $(\mathrm{CBN})$.

Lagos State that is referred to as the 'Centre of Excellence' and the financial capital of Nigeria, all the banks are fully represented and due to rapid development and the fact that Lagos is one of the most developed economies of Nigeria, this has greatly affected marketing activities of banks operating in the State. Hence the effect of marketing of financial services in the industry and its effort to boost the profit base of the industry. The outcomes of the banking sector recapitalization also provide another competitive level in the banking industry. This new era has provide series of new innovation into marketing of bank services, has these innovation translate into performance in the industry.

\subsection{Objectives of Study}

The main objective of the paper is analyses the impact of marketing of financial services on the financial performance of banking in Nigeria. Other specific objectives are:

a) To enumerate the relationship between marketing of banking service and bank profitability

b) To determine if performance has any correlation to marketing strategy adopted in banking industry.

\subsection{Research Questions}

Therefore the research questions to be answered in this research work are:

* What are the relationship between marketing of banking service and profitability of the bank in Nigeria?

* What are the correlation between marketing strategy adopted and productivity of the banking industry?

\subsection{Research Hypotheses}

The hypotheses is formulated in pair of Null hypothesis $\left(\mathrm{H}_{\mathrm{O}}\right)$ which represent the negative part of the hypothesis and Alternative Hypothesis $\left(\mathrm{H}_{\mathrm{A}}\right)$ the positive side of the hypothesis thus: 


\section{Hypothesis I}

$\mathrm{H}_{\mathrm{O}}$ : There is no significant relationship between marketing of banking services and profitability of banking industry in Nigeria

$\mathrm{H}_{\mathrm{A}}$ : There is relationship between marketing of banking services and profitability of banking industry in Nigeria. Hypothesis II

$\mathrm{H}_{\mathrm{O}}$ : There is no significant correlation between marketing strategy adopted and productivity of the banking industry

$\mathrm{H}_{\mathrm{A}}$ : There is correlation between marketing strategy adopted and productivity of the banking industry

\subsection{Significance of the Study}

The significance of this study is to look at the effect of marketing activities in the banking sector of the economy. Establish the fact that despite the fact that recapitalization is a veritable means of fostering Industrial growth yet the industry need to enlighten the public on the service rendered in the industry.

Every firm will be grateful to learn ways of raising fund and enjoy all the services render by their bankers. Thus, this research is intended to be of immerse benefit to manufacturing firms, financial planners and researchers in the field of banking and finance.

\subsection{Plan of Study}

This paper is organize in four section, section I entails the background of the study, statement of problem, objectives of the study, research questions, significance of the study and statement of research hypothesis. Section II comprises of literature review, theoretical framework and conceptual approaches while section III focuses on how the paper was conducted; it describes the methodology used as well as analytical process of the paper. Section IV is the concluding section where the results of the analyses are interpreted, policy issues are treated as well as recommendations on the outcome of the research.

\section{Section II: Literature Review}

Banking came into existence as a result of problem of barter system due to its attendant problems such as medium of exchange crisis, multiplicity of coins and commodity money, just to mention but a few which affects the growth of the economy of developing nations. Modern day banking plays significant roles in economic growth and development which vary from country to another depending on the economic political and legal system where in which the banks operate (Allen, 2004).

\subsection{Conceptual Framework}

Modem banking according to Sanusi (2001) commenced in Nigeria during the second half of the nineteenth century; when Elder Dempster started the movement of money in specie from one part of the country to another in other to boost its shipping business. Thus, the banking industry predates Nigeria and her attainment of political independence.

Commercial banking provides a major institutional mechanism for the mobilization of resources from the surplus units and for channeling to the deficit units through the extension of credits. The efficiency with which this is done greatly influences the savings and investment process and has implications on the management of the economy and the attainment of sustainable growth and development. The importance of the commercial banking system in the economic development of any nation underscores the need for adequate analysis and documentation. Unugbro (2007) observed that banks offer numerous services to the general public which includes;

* Mobilization of Savings: They accept deposits from their customers on current savings, and time deposit accounts. These deposits are considered safe and yield interest to their customers.

* Issuance of Loans and Advances: They give credit advances to their customers in the form of loans and overdrafts. These services yield returns to the banks in the form of interest on the services rendered.

* Money Creation Functions: they create and expand the scope of money supply in the economy. They do this by granting loans and advances to their customers.

* Acts as customer's Agent: They make payment and receipt on behalf of their customers. Such agency functions include payments like insurance premiums, stock and shares transactions and standing orders.

\subsection{Marketing and Financial Services}

The primary objective of sales promotion within the financial services sector is to attract new customers, to increase the level of deposit accounts, thereby increasing the bank's share of the market. Increased competition in the Financial Service sector has made prices more transparent, and therefore price competitions have become more common. Market conditions have increased the use of price promotions to increase short-term sales (Harrison, 2000).

Becker et. al identify five contributors to the increasing use of sales promotion in financial service as; 
* Rising prices and advantage clutter erode mass-media advertising cost-effectiveness while consumers become more desensitized to it.

* Due to the increased use of sales promotions by market leaders, it has become more respectable part of the promotional mix.

* Shortening planning horizons make short-term promotions more attractive.

* Fragmentation of the markets call for more tailored and targeted communication.

* Many markets, promotions have become so common that firms are obliged to follow or risk losing market shares.

Cohen (2008) posited that sales Promotion refers to many kinds of incentives and techniques directed towards consumers and traders with the intention to provide immediate or short-term sales effects. But Alford (2011) observed that sales promotion includes incentive-offering and interest-creating activities which are generally short-term marketing events other than advertisement, personal selling, publicity, and direct marketing. The purpose of sales promotion is to stimulate, motivate, and influence the purchase and other desired behavioural responses of the firm's customers. While Peattie and Peattie, (1994) defines Sales Promotion as marketing activities usually specific to a time period, place or customer group, which encourage a direct response from consumer or market intermediaries, through the offer of additional benefits. Sales Promotion offers a direct inducement to act by providing extra worth over and above what is built into the product at its normal price. These temporary inducements are offered usually at a time and place where the buying decision is made. Today, we find companies in almost all sectors offering some sort of a promotion scheme.

In the literature, services are distinguished from goods by their unique characteristics, which are intangibility, inseparability, perishability and heterogeneity (Harrison, 2000; Howcroft, Hewer \& Hamilton, 2003). However McKechnie (2009) adds two characteristics that are common to financial services; fiduciary responsibility and two-way information flow and Beckett (2010) includes three additional characteristics that distinguish financial services from other goods, these are transparency of performance, uncertainty of outcome and poor comparability.

Alford (2011) observed that literature has differentiated goods from services and posited that goods and services cannot be seen as polar extremes to one another and even within services, there are variations. Only in the branch of financial services can great variety be found in the differences of characteristics. Thus, while the characteristics are widely accepted, one must still bear in mind that exceptions to the general rules do exist.

\subsection{Banking Service in Nigeria}

Nigerian banking came into the $21^{\text {st }}$ century with every high hopes, especially that the apocalyptic millennium computer glitches that were predicted globally never happened. At that time, most of the banks were not internationally competitive, both in terms of size and the volume and the kind of transactions they handled. The 90 banks in operation in year 2001 had 2,994 branches, aggregate total assets of 2.167 trillion naira, total deposits of 947.18 billion Naira and capital and reserves of 172.42 billion. Their contribution together with other financial sector sub sector to national economic growth was limited to $12.13 \%$ of the GDP in 2001 .

The first phase bank reforms of 2005 end on 31 December, when the minimum capital requirement was raised to 25 billion Naira within time frame. Okwokwo (2006) posited that the consolidation in the industry was unprecedented anywhere in the world with number of institutions that combined into one entity before the time frame. From institution of about 89 banking institution to 25 banks that emerged at the end of the 2005 which later resulted to further consolidation within the year resulting to merger of two other banks bring the number to 24 banks, this marked the era of modern banking in Nigeria.

Another round of reforms were initiated, it started with decisive action of the regulatory body $-\mathrm{CBN}$ on the issue of non performing loans and with the setting of Asset Management Corporation of Nigeria (AMCON) and recapitalization of the troubled banks which give the banks new lease of life. Sanusi implement other measures are:

* The replacement of Managing/Executive Directors of eight (8) of banks that were identified as the main sources of instability in the sector,

* Injection of 620 billion Naira as liquidity support for the insolvent/ailing banks,

* Establishment and commencement of operation by the Asset Management Corporation of Nigeria (AMCON) which purchase non performing loans and advances from the banks which resulted to reduction of ratio of non performing loan to gross loan and advances from $32.8 \%$ in December 2009 to $15.5 \%$ in December of 2010. Embarking on recapitalization of technical insolvent banks.

* Revised code of corporate governance, which led to the exit of the Managing Directors/Chief Executive Officers (MD/CEO) that had spent ten (10) years and above in that capacity. This policy affect CEO's of Skye Bank Plc, United Bank for Africa Plc and Zenith Bank Plc.

* Bank structure consolidation and uniform accounting year end.

* New banking model, comprising commercial, merchant and specialized banks, 
* New Prudential Guidelines were introduced;

* Criminal prosecution of errant top management of the technically insolvent banks;

* Development of a supervisory framework to provide an early warning signal on troubled banks;

* Mandatory adoption of International Financial Reporting Standard (IFRS) with a deadline of $1^{\text {st }}$ January 2012

* Memorandum of Understanding on Cross Border supervision of banks engaged in cross border banking;

* Guidelines issued for institutions offering non interest financial services;

* Take over or nationalized of three (3) troubled banks that had difficult in recapitalization.

The next round of reforms determine the extent of banking operations where;

- Regional bank required minimum capital base of 10 billion Naira and can only operate in six to twelve states in Nigeria.

- National banks are required to have minimum capital base of 25 billion Naira and operate in all the region in the country

- International banks licence comes with a minimum capital of 50 billion. It allow such to operate offshore.

Also banks are required to concentrate fully on core banking rather fiddling with non-banking financial services. These new model required banks to either sell all non core banking businesses or form a holding company if they intent to carry out other non-banking financial services including insurance, asset management and capital market activities. Five banks-First City Monument Bank Plc (FCMB), First Bank of Nigeria Plc (FBN), Stanbic IBTC bank Plc, united Bank for Africa Plc (UBA) and Union Bank of Nigeria (UBN) have already opted to keep their subsidiaries while other banks including Access Bank Plc, Diamond Bank Plc, Fidelity Bank Plc, Guaranty Trust Bank Plc (GTB), Skye Bank Plc, Zenith bank Plc and WEMA Bank Plc are pursuing divestment from non-banking subsidiaries. Besides, the sphere-based capitalization has thrown Nigerian banks into three groups. WEMA Bank which sees competitive advantages in its strong presence in the dominant South-West market has chosen to be a regional banks; duo of Sterling bank Plc and Unity bank has chosen to be national banks while others have opted for international licence. Already CBN has granted Approvals-In-Principle (AIPs) for commercial banking licence to 17 banks comprising of nine international banks, six national banks and two regional banks.

The philosophy of marketing concept teaches that to succeed in any business, the customer must be the centerpiece of the business' activities this was bound out of the saying that "the customer is king". For a longtime, Nigerian banks had operated in the sellers market and the customers had been at the receiving end, the situation has changed and is still changing, development within and outside the country have made Nigerian banks to appreciate the need to put the customer at the center of their activities. Meanwhile various products including smart cards, Automated Teller Machines (ATM), ebanking and other new services which including flexible banking hours.

\subsection{The Promotion Mix for Banking Services}

Promotion is according to Brassington and Petit (2000) "the direct way in which an organisation communicates the product or service to its target audiences." Within the financial service industry, promotion is used in many different ways (Meidan, 1996). Brassington and Petit, 2000 categorized the promotional tools into five main elements:

Advertising: Brassington and Petit (Op.cit) define advertising as "any paid form of non-personal communication directed towards target audiences and transmitted through various mass media in order to promote and present a product, service or idea". The key difference between advertising and the other promotional tools is that it is impersonal and communicates with large numbers of people through paid media channels.

Meidan (1996) states that a financial service organisation can use its advertising for either its short-term or its long-term objectives. A bank attempting to generate a long-term build-up of its name would use institutional advertising, while a bank interested in promoting its brand name and its different services would use a brand advertising policy.

Sales promotion: There is no common definition of sales promotion found on literature. Peattie and Peattie (2004) define sales promotion as "marketing activities usually specific to a time period, place or customer group, which encourage a direct response from consumer or marketing intermediaries, through the offer of additional benefits..

Kotler (2006) defines sales promotion as a "short-term incentive to encourage the purchase or sale of a product or service.. By definition, sales promotion can be directed either to customers or channeled to intermediaries and it is used to encourage immediate action. In the literature, sales promotions are broadly categorized to value adding (non-price promotions) or value increasing promotions (price-based promotions).

Public Relations: According to Brassington and Petit, 2000, the essence of Public Relations (PR) is to look after 
the nature and quality of the relationship between the organisation and its different publics, and to create a mutual understanding. Public Relations cover a wide range of activities, for example the creation and maintenance of corporate identity and image; charitable involvement, such as sponsorship and community initiatives; media relation for the spreading of good news, as well as for crisis management, such as damage limitation. Moreover, an organisation can attend trade exhibitions to create stronger relationships with key suppliers and customers as well as enhancing the organisation's presence and reputation within the market.

Meidan states that another part of Public Relations is the publicity gained through magazines. Financial services obtain considerable publicity in so-called quality press, such as financial journals.

Personal Selling: Brassington and Petit define Personal Selling to be "a two-way communication tool between a representative of an organisation and an individual or group, with the intention to inform, persuade or remind them, or sometimes serve them to take appropriate actions." Furthermore, Personal Selling is a crucial element in encouraging customers' post-purchase satisfaction, and in building profitable long-term buyer-seller relationships built on trust and understanding.

Direct marketing: According to Brassington and Petit (2000) direct marketing is an interactive system of marketing using one or more advertising media to achieve measurable response anywhere, forming a basis for creating and further developing an on-going direct relationship between an organisation and its customers. To be able to create and sustain quality relationship with sometimes hundreds or even thousands of individual customers, an oraganisation needs to have as much information as possible about each one and needs to be able to access, manipulate analyse the information. Thus, the database is crucial to the process of building the relationship.

Lee (2002) states that the fast advances in technology over the past thirty years have reshaped how customers today interact with their financial institution. The financial sector has extended its "face-to-face" selling towards direct marketing of products and services in the form of phone, mail, computer transactions.

Mols, 2000 claims that as computer literacy and the availability of computers increase and the cost decrease, internet-banking consumers are increasing day by day. Through the internet banks, the customers can identify what interests them. Furthermore, the internet technology also makes it possible to follow individual customer usage. With the information gathered in an integrated database, it is possible to read the customers' needs and satisfy them. This knowledge can be used for different kinds of Direct Marketing.

\subsection{Historical Background of UBA Plc}

The United Bank for Africa PLC (UBA) has its antecedent in The British and French Bank which metamorphosed from Banque National Le commerce et L'industrie, BNCI, Paris established in 1932. In May 1994, the British and French Bank began operations in Nigeria at 117, Broad Street in Lagos. The Bank went public in 1960 in accordance with the policy and intention of the French owners of the Bank to sell some of its shares to Nigerians.

UBA PLC was incorporated on February 23rd 1961, to take over the assets and liabilities of the British and French Bank. UBA PC was the first of the international banks operating in Nigeria at that time to be registered under Nigeria Law. Its paid up capital was over N4 million. And by 1961, the bank had grown from its one office structure to ten branches located in Lagos, Kano, Kaduna and Prot Harcourt. And today, the bank has 220 branches and cash offices in Nigeria' major commercial centers. State capitals and federal capital territory with two offshore branches in New York and Grand Cayman Island. UBA PLC retains the unique status of being the only Nigerian Bank with presence in the United States of America. The New York branch acts as one of the oversea correspondent banks.

Through its progressiveness and dynamism in International banking, UBA has established affirm presence in the major financial centers of the world. And in 1970, the Bank undertook a voluntary public issue, the first such public to be undertaken bay a bank in Nigeria. This voluntary issue came years before the requirement by authorities for $60 \%$ Nigerian Equity participation in social banks.

UBA PLC became a private entity in 1994 with the full divestment of government $60 \%$ share holding under its privatization and commercialization of Public Enterprise Trust. UBA has witnessed a phenomenal growth and expansion since its inception within three decades of its incorporation, UBA's outstanding performance in within three decades of its attributed to the willingness too first class banking services are being a corporate citizen.

The Bank is strongly committed to the social responsibilities and contributes meaningfully to the development of communities in which it's represented. The bank has within the last 39 years attained a number of first in the banking industry in 39 years of its existence; the bank has taken a giant stride to become the one bank in Black Africa.

The main organization unit of UBA is the sector within which are sub sector, Division, Department, Groups, Teams and Units in that order. The head office structure has saving banking operations as follows: Northwest Banking, Northeast, Southwest Banking, Lagos North Banking, Lagos South Banking, South West Banking and Southeast Banking. The seven banking operations coordinate the Regional offices of Kano, Maiduguri, Abuja, 
Lagos, Ibadan and Port Harcourt.

The overall organization structure has the Board of Directors at the apex to whom the Managing Director and Chief Executive reports. The Managing Director in turn has five general managers reporting to him. These are: General Manager (Special duties, MD's office), Assistance General Manager (Company Secretary), Deputy General Manager (UBA Trustees LTD). Also reporting directly to the Managing and Chief Executives are eight line managers. These line managers consist of five executive Directors, two Assistance General Managers and A general Manager. The five Executive Directors are those for corporate and consume sector, commercial banking and public sector, MOT services, operations and Inf. Tech. sector and for credit risk Management sector. The two Assistance General Mangers are those for Financial and Control Division and Special Assistance to MD and Head Strategies Management Divisions. The General Manager (General Administration and Corporate Affairs) also reports directly to the Managing Director. Also the eight line managers each have some managers they work with. Communication is vertical in the sense that these managers' works according to instructions given to them by their line managers and these line managers also receive feedback from them. This makes dissemination more efficient and effective.

\subsection{Research Methodology}

This chapter considers the framework for research method adopted for paper,

\subsection{Research Design}

The framework for gathering information for this research work was descriptive (survey) design using the questionnaire as the main instruments.

\subsection{Sample size and Population of the Study}

The study population comprises of branches of United Bank for Africa Plc (UBA Plc) in Nigeria and for proximity the UBA Plc branches in Badagry Branch, Alaba Branch Ojo, Egbeda Branch Egbeda and Ikeja Branch Ikeja all in Lagos are selected. The survey population of this study is made up of 100 randomly selected staff and customers of United Bank of Africa Pc.

\subsection{Research Instrument}

The questionnaire design is used as the research instrument for gathering information in the study. It is designed in simple English language consists of two sections: section A is the Bio data, section B deals items relating to the objective of the study and hypothesis which will provide the relevant information needed to aid the research work.

Structured Questionnaire is used where the respondents are restricted to some response options. The five points scale response was adopted for this study and are coded as 5, 4,3,2,1 as Strongly Agree, Agree, Undecided, Disagree and Strongly Disagree respectively.

\subsection{Questionnaire Administration}

Questionnaire was self administered by the researcher aided by the technical staff of the marketing and sales department of the bank.

\subsection{Validity and reliability test}

Validity test is defined as the degree to which the instruments of data collection measures what it has been designed to measure consistently and efficiently. For the validity test, test-retest method of reliability was adopted out of all the various types of measures. The Cronbach's alpha co-efficient will be used to test the questionnaires to ensure the consistency of the research instrument. While Reliability refers to the extent to which assessments are consistent that is the degree to which a test is free from measurement errors (Fraenkel \& Wallen, 2003;

\subsection{Method of Data Analysis}

The data analysis was edited and analyzed using the percentage and charts while the section was analyzed to test the hypotheses formulated using non parametric statistical tool of Chi-Square $\left(X^{2}\right)$ considered the most appropriate in this research work because of its simplicity of application. The formula for the calculation of $\mathrm{X}$ is given as

$$
\chi^{2}=\sum \frac{(\mathrm{O}-\mathrm{E})^{2}}{\mathrm{E}}
$$

Where

$$
X^{2}=\text { Chi-square }
$$


$0=$ The Observed frequency

$\mathrm{E}=$ The Expected frequency

$\sum=$ Summation

\section{The Decision Rule}

Accept the Null hypothesis if the $\mathrm{X}^{2}$ calculated is less that the tabulated $\chi^{2}$, Reject the Null hypothesis if the $\mathrm{X}^{2}$ calculated is greater than the tabulated $\left(\chi^{2}\right)$.

\subsection{Data Analysis}

Hundred questionnaires were distributed and out of these ninety (90) questionnaires were returned. Out of the ones return six (6) of the questionnaires were not filled and four of it is improperly filled in the sense that either the respondents did not know how to fill or they were not willing to supply the information required. Eighty (80) questionnaires were certified fit enough to be collated for the analysis and interpretation of the results.

In Section $\mathrm{A}$ the Respondents distribution according to Branch show that Badagry Branch have 22 respondents or 27.50 percent of total respondents, Alaba Branch with 18 respondents or 22.50 percent, Egbeda Branch with 24 respondents or $\quad 30$ percent and Ikeja Branch with 16 respondents or 20 percent of the total respondents. Respondents distribution according to gender shows that out of the eighty questionnaires accepted as valid for analysis, 48 respondents are male representing 60 percent of the respondents while $40 \%$ or 32 respondents are female. The analyses also show that the percentage of the married group is 56 percent which is higher than the singles which comprises of divorcees, widower and widows. The bulk of the work forces are between the ages of 31 to 40 years of age.

Distribution of respondents according to educational qualification shows that the majority of workers in the sector have a HND or BSc with 37.5 percent while 12.5 percent have secondary education, National Diploma and professional certificate. Also from the analyses of section A, the comment of the respondents, show that low Management respondents are in the majority with 77.5 percent and top management with 10 percent.

And that the distribution of respondents according to working experience status show that majority of the respondents has spent above 11 years in the organization with 57.5. While the least are between 5 to 10 years with 15 percent. Therefore are adjudge to be able to provide accurate responses to items in the questionnaire.

Analysis of Section B Concern Bank Customers

\begin{tabular}{|c|c|c|c|c|c|c|}
\hline \multirow[t]{2}{*}{ SN } & \multirow[t]{2}{*}{ Item } & \multicolumn{5}{|c|}{ Response } \\
\hline & & 5 & 4 & 3 & 2 & 1 \\
\hline 1 & $\begin{array}{l}\text { Customers were encourage to open account in } \\
\text { then bank due to ongoing promo }\end{array}$ & $\begin{array}{c}48 \\
(60 \%)\end{array}$ & $\begin{array}{c}16 \\
(20 \%)\end{array}$ & $\begin{array}{c}4 \\
(5 \%)\end{array}$ & $\begin{array}{c}12 \\
(15 \%)\end{array}$ & $\begin{array}{c}0 \\
(0 \%)\end{array}$ \\
\hline 2 & $\begin{array}{l}\text { Customers were encourage to open account in } \\
\text { then bank due to on going promo }\end{array}$ & $\begin{array}{c}48 \\
(60 \%)\end{array}$ & $\begin{array}{c}16 \\
(20 \%)\end{array}$ & $\begin{array}{c}4 \\
(5 \%)\end{array}$ & $\begin{array}{c}12 \\
(15 \%)\end{array}$ & $\begin{array}{c}0 \\
(0 \%)\end{array}$ \\
\hline 3 & Advertisement encouraged to open account & $\begin{array}{c}44 \\
(55 \%)\end{array}$ & $\begin{array}{c}18 \\
(22.5 \%)\end{array}$ & $\begin{array}{c}4 \\
(5 \%)\end{array}$ & $\begin{array}{c}8 \\
(10 \%)\end{array}$ & $\begin{array}{r}6 \\
(7.5 \%)\end{array}$ \\
\hline 4 & $\begin{array}{l}\text { Sales promotion has help to introduce the } \\
\text { product of the bank. }\end{array}$ & $\begin{array}{c}74 \\
(80 \%)\end{array}$ & $\begin{array}{c}10 \\
(12.5 \%)\end{array}$ & $\begin{array}{c}2 \\
(2.5 \%)\end{array}$ & $\begin{array}{c}3 \\
(3.75 \%)\end{array}$ & $\begin{array}{c}1 \\
(1.25 \%)\end{array}$ \\
\hline 5 & Most of bank's products are satisfactory & $\begin{array}{c}42 \\
(52.5 \%)\end{array}$ & $\begin{array}{c}20 \\
(25 \%)\end{array}$ & $\begin{array}{c}4 \\
(5 \%)\end{array}$ & $\begin{array}{c}8 \\
(10 \%)\end{array}$ & $\begin{array}{r}6 \\
(7.5 \%)\end{array}$ \\
\hline 6 & $\begin{array}{l}\text { Promotional activities of the bank are } \\
\text { encouraging to buy the financial product of the } \\
\text { bank }\end{array}$ & $\begin{array}{c}20 \\
(25 \%)\end{array}$ & $\begin{array}{c}40 \\
(50 \%)\end{array}$ & $\begin{array}{c}4 \\
(5 \%)\end{array}$ & $\begin{array}{c}8 \\
(10 \%)\end{array}$ & $\begin{array}{c}8 \\
(10 \%)\end{array}$ \\
\hline 7 & $\begin{array}{l}\text { Sales promotion increase cash deposit in the } \\
\text { bank }\end{array}$ & $\begin{array}{c}40 \\
(50 \%)\end{array}$ & $\begin{array}{c}16 \\
(20 \%)\end{array}$ & $\begin{array}{c}4 \\
(5 \%)\end{array}$ & $\begin{array}{c}12 \\
(15 \%)\end{array}$ & $\begin{array}{c}8 \\
(10 \%)\end{array}$ \\
\hline 8 & $\begin{array}{l}\text { Account were reactivated as a result of } \\
\text { ongoing sales promo }\end{array}$ & $\begin{array}{c}70 \\
(96.25 \%)\end{array}$ & $\begin{array}{c}8 \\
(10 \%)\end{array}$ & $\begin{array}{c}0 \\
(0 \%)\end{array}$ & $\begin{array}{r}2 \\
(2.5 \%)\end{array}$ & $\begin{array}{c}0 \\
(0 \%)\end{array}$ \\
\hline 9 & $\begin{array}{l}\text { Level of deposit are maintain after expiration } \\
\text { of promotional activities }\end{array}$ & $\begin{array}{c}34 \\
(42.5 \%)\end{array}$ & $\begin{array}{c}20 \\
(25 \%)\end{array}$ & $\begin{array}{c}8 \\
(10 \%)\end{array}$ & $\begin{array}{c}14 \\
(17.5 \%)\end{array}$ & $\begin{array}{c}4 \\
(5 \%)\end{array}$ \\
\hline 10 & Most of bank's products are satisfactory & $\begin{array}{c}42 \\
(52.5 \%)\end{array}$ & $\begin{array}{c}20 \\
(25 \%)\end{array}$ & $\begin{array}{c}4 \\
(5 \%)\end{array}$ & $\begin{array}{c}8 \\
(10 \%)\end{array}$ & $\begin{array}{r}6 \\
(7.5 \%)\end{array}$ \\
\hline 11 & $\begin{array}{l}\text { Sales promotion has effect on marketing of } \\
\text { financial services }\end{array}$ & $\begin{array}{c}20 \\
(25 \%)\end{array}$ & $\begin{array}{c}40 \\
(50 \%)\end{array}$ & $\begin{array}{c}0 \\
(0 \%)\end{array}$ & $\begin{array}{c}12 \\
(15 \%)\end{array}$ & $\begin{array}{c}8 \\
(10 \%)\end{array}$ \\
\hline 12 & $\begin{array}{l}\text { Sales promotion encourage introduction of } \\
\text { new product in the bank }\end{array}$ & $\begin{array}{c}48 \\
(60 \%)\end{array}$ & $\begin{array}{c}16 \\
(20 \%)\end{array}$ & $\begin{array}{c}4 \\
(5 \%)\end{array}$ & $\begin{array}{c}12 \\
(15 \%)\end{array}$ & $0(0 \%)$ \\
\hline
\end{tabular}




\begin{tabular}{|c|c|c|c|c|c|c|}
\hline \multirow[t]{2}{*}{ SN } & \multirow[t]{2}{*}{ Item } & \multicolumn{5}{|c|}{ Response } \\
\hline & & 5 & 4 & 3 & 2 & 1 \\
\hline 13 & $\begin{array}{l}\text { Sales promotion increase the opening of new } \\
\text { accounts }\end{array}$ & $\begin{array}{c}44 \\
(55 \%)\end{array}$ & $\begin{array}{c}18 \\
(22.5 \%)\end{array}$ & $\begin{array}{c}4 \\
(5 \%)\end{array}$ & $\begin{array}{c}82 \\
(10 \%)\end{array}$ & $\begin{array}{r}6 \\
(7.5 \%)\end{array}$ \\
\hline 14 & $\begin{array}{l}\text { The level of cash deposit by customers during } \\
\text { sales promotion is sustained after sales } \\
\text { promotion }\end{array}$ & $\begin{array}{c}64 \\
(80 \%)\end{array}$ & $\begin{array}{c}10 \\
(12.5 \%)\end{array}$ & $\begin{array}{c}2 \\
(2.5 \%)\end{array}$ & $\begin{array}{c}3 \\
(3.75 \%)\end{array}$ & $\begin{array}{c}1 \\
(1.25 \%)\end{array}$ \\
\hline 15 & $\begin{array}{l}\text { Sales promotion increases the deposit base of } \\
\text { the bank }\end{array}$ & $\begin{array}{c}42 \\
(52.5 \%)\end{array}$ & $\begin{array}{c}20 \\
(25 \%)\end{array}$ & $\begin{array}{c}4 \\
(5 \%)\end{array}$ & $\begin{array}{c}8 \\
(10 \%)\end{array}$ & $\begin{array}{r}6 \\
(7.5 \%)\end{array}$ \\
\hline 16 & $\begin{array}{l}\text { Sales promotion increases the asset base of the } \\
\text { bank }\end{array}$ & $\begin{array}{c}20 \\
(25 \%)\end{array}$ & $\begin{array}{c}40 \\
(50 \%)\end{array}$ & $\begin{array}{c}4 \\
(5 \%)\end{array}$ & $\begin{array}{c}8 \\
(10 \%)\end{array}$ & $\begin{array}{c}8 \\
(10 \%)\end{array}$ \\
\hline 17 & $\begin{array}{l}\text { Fund expended on sales promotion are } \\
\text { justified }\end{array}$ & $\begin{array}{c}40 \\
(50 \%)\end{array}$ & $\begin{array}{c}16 \\
(20 \%)\end{array}$ & $\begin{array}{c}4 \\
(5 \%)\end{array}$ & $\begin{array}{c}12 \\
(15 \%)\end{array}$ & $\begin{array}{c}8 \\
(10 \%)\end{array}$ \\
\hline 18 & $\begin{array}{l}\text { Sales promotion increase efficiency in the } \\
\text { bank }\end{array}$ & $\begin{array}{c}40 \\
(50 \%) \\
\end{array}$ & $\begin{array}{c}16 \\
(20 \%) \\
\end{array}$ & $\begin{array}{c}4 \\
(5 \%) \\
\end{array}$ & $\begin{array}{c}12 \\
(15 \%)\end{array}$ & $\begin{array}{c}8 \\
(10 \%) \\
\end{array}$ \\
\hline 18 & $\begin{array}{l}\text { Sales promotion increase efficiency in the } \\
\text { bank }\end{array}$ & $\begin{array}{c}70 \\
(87.5 \%) \\
\end{array}$ & $\begin{array}{c}8 \\
(10 \%)\end{array}$ & $\begin{array}{c}0 \\
(0 \%)\end{array}$ & $\begin{array}{r}2 \\
(2.5 \%)\end{array}$ & $0(0 \%)$ \\
\hline 19 & $\begin{array}{l}\text { Overall the bank performance increase as } \\
\text { results of sales promotion }\end{array}$ & $\begin{array}{c}34 \\
(42.5 \%)\end{array}$ & $\begin{array}{c}20 \\
(25 \%)\end{array}$ & $\begin{array}{c}8 \\
(10 \%)\end{array}$ & $\begin{array}{c}14 \\
(17.5 \%)\end{array}$ & $4(5 \%)$ \\
\hline
\end{tabular}

\section{Testing of Hypotheses}

The hypotheses earlier formulated will now be tested and the result will be analyzed using non-parametric statistical tool of Chi-Square at $95 \%$ degree of confidence or in other words at 0.05 level of significance.

\section{Hypothesis I}

$\mathrm{H}_{\mathrm{O}}$ : There is no significant relationship between marketing of banking services and profitability of banking industry in Nigeria

$\mathrm{H}_{\mathrm{A}}$ : There is relationship between marketing of banking services and profitability of banking industry in Nigeria.

Extract of Chi-Square statistic based on computer aided statistical package of Statistical Package for Social Scientists is presented below;

Table 20 A: Chi Square Extract (Test Statistics Appendix II)

\begin{tabular}{|c|c|c|c|c|c|c|}
\hline Question & Responses & $\%$ & $\mathrm{X}^{2} \mathrm{Cal}$ & $X^{2}$ Tab & DF & Remark \\
\hline \multirow[t]{4}{*}{7} & Strongly Agree & 68.33 & & & & \\
\hline & Agree & 14.17 & & & & \\
\hline & Disagree & 15.0 & & & & \\
\hline & Strongly Disagree & 2.5 & 48.50 & & 3 & \\
\hline \multirow[t]{4}{*}{9} & Strongly Agree & 80.0 & & & & \\
\hline & Agree & 10.0 & & & & \\
\hline & Disagree & 8.33 & $38.780^{\mathrm{a}}$ & & 3 & \\
\hline & Strongly Disagree & 1.67 & & & & \\
\hline \multirow[t]{4}{*}{11} & Strongly Agree & 30.0 & & & & \\
\hline & Agree & 55.0 & & & & \\
\hline & Disagree & 10.0 & & & & \\
\hline & Strongly Disagree & 5.0 & $102.380^{\mathrm{a}}$ & & 3 & \\
\hline \multirow[t]{4}{*}{21} & Strongly Agree & 39.17 & & & & \\
\hline & Agree & 50.0 & & & & \\
\hline & Disagree & 9.17 & & & & \\
\hline & Strongly Disagree & 1.67 & $98.060^{\mathrm{a}}$ & & 3 & \\
\hline Total & & & 386.68 & 15.507 & 12 & Sig \\
\hline
\end{tabular}

$\mathrm{X}^{2} \mathrm{Cal}=386.68, \mathrm{X}^{2}$ table $=21.026$, Degree of Freedom $(\mathrm{df})=12$ at 0.05 Level of Significance $(\mathrm{LS})$.

Decision

Table above presents the Chi-square analyses of the responses in section B used for the analyses of hypothesis I. The result indicates that the Chi square calculated $\left(\mathrm{X}^{2}\right.$ cal $)$ is 386.68 while Chi square table $\left(\mathrm{X}^{2}\right.$ tab) is 21.026 with degree of freedom (df) $=8$ at 0.05 Level of Significance (LS). It is observed that Chi square $\left(\mathrm{X}^{2}\right)$ Table is less than Chi square $\left(\mathrm{X}^{2}\right)$ Calculated therefore reject the null hypothesis and accept the alternate hypothesis that There is relationship between marketing of banking services and profitability of banking industry in Nigeria.

Hypothesis II

$\mathrm{H}_{\mathrm{O}}$ : There is no significant correlation between marketing strategy adopted and productivity of the banking 
industry

$\mathrm{H}_{\mathrm{A}}$ : There is correlation between marketing strategy adopted and productivity of the banking industry

Test Statistics

Table 21: Chi Square Extract (Test Statistics Appendix II)

\begin{tabular}{|c|c|c|c|c|c|c|}
\hline Question & Responses & $\%$ & $\mathrm{X}^{2} \mathrm{Cal}$ & $\mathrm{X}^{2} \mathrm{Tab}$ & DF & Remark \\
\hline \multirow[t]{4}{*}{13} & Strongly Agree & 12.5 & & & & \\
\hline & Agree & 60.0 & & & & \\
\hline & Disagree & 25.0 & & & & \\
\hline & Strongly Disagree & 2.5 & $144.300^{\mathrm{a}}$ & & 4 & \\
\hline \multirow[t]{4}{*}{14} & Strongly Agree & 50.00 & & & & \\
\hline & Agree & 30.0 & & & & \\
\hline & Disagree & 20.0 & & & & \\
\hline & Strongly Disagree & 0.0 & $63.900^{\mathrm{a}}$ & & 4 & \\
\hline \multirow[t]{4}{*}{17} & Strongly Agree & 50.00 & & & & \\
\hline & Agree & 40.0 & & & & \\
\hline & Disagree & 7.5 & & & & \\
\hline & Strongly Disagree & 2.5 & $59.300^{\mathrm{a}}$ & & 4 & \\
\hline \multirow[t]{4}{*}{18} & Strongly Agree & 65.0 & & & & \\
\hline & Agree & 31.67 & & & & \\
\hline & Disagree & 2.5 & & & & \\
\hline & Strongly Disagree & 0.83 & $82.300^{\mathrm{a}}$ & & 4 & \\
\hline \multirow{4}{*}{19} & Strongly Agree & 52.5 & & & & \\
\hline & Agree & 31.67 & & & & \\
\hline & Disagree & 15.0 & & & & \\
\hline & Strongly Disagree & 0.25 & $70.500^{\mathrm{a}}$ & & 4 & \\
\hline Total & & & 420.300 & 31.410 & 20 & Sig \\
\hline
\end{tabular}

Table above presents the Chi-square analyses of the responses in section B used for the analyses of hypothesis I. The result indicates that the Chi square calculated $\left(\mathrm{X}^{2}\right.$ cal) is 420.3 while Chi square table $\left(\mathrm{X}^{2}\right.$ tab) is 31.410 with degree of freedom (df) $=20$ at 0.05 Level of Significance (LS). It is observed that Chi square $\left(\mathrm{X}^{2}\right)$ Table is less than Chi square $\left(\mathrm{X}^{2}\right)$ Calculated therefore reject the null hypothesis and accept the alternate hypothesis that there is correlation between marketing strategy adopted and productivity of the banking industry.

\subsection{Summary, Conclusion and Recommendation}

In Nigeria's economic history, the strides of the year 2011 been internationally acclaimed, was unprecedented. The many reforms that have engendered the current success have largely included those in the financial sector, particularly, the positive policy shifts in the domestic money market as a first step towards a more robust and enduring facilities for the sector. Parts of the expectations are that the improved enabling environment from the reforms would continue to make more investment funds really available through savings.

Marketing practice tended to be seen as a creative industry that included advertising, distribution and selling. The philosophy of marketing concept teaches that to succeed in any business, the customer must be the centerpiece of firms' activities, the saying "the customer is king" "the customer is a dictator, the customer is god, are all bone out of the philosophy. Marketing is an integral part of the strategic planning process. The nature of marketing activity, which an organization should engage in has substantial interest from both academics and business executives.

\subsection{Summary of Findings}

It was discovered that majority of respondents agree that they were encouraged to open an account due to sales promotion by the bank and the advertisement. Also that sales promotion in form of advertisement has help to introduce new products in the bank and this has increase the sales of the bank. This has have increase deposits liabilities of the bank even after the expiration of sales promotion. It is then concluded that marketing of banking services has correlation to profitability of the industry in Nigeria.

Also the respondents agree that sales promotion has great effect on marketing of financial services and that sales promotion encouraged and reactivation of dormant accounts. This invariably justified fund expended on sales promotion.

It helps to increase the sales promotion increases the asset base of the bank and increase efficiency in the bank, this increase the bank performance. 
Therefore marketing strategies employed has improved the performance of banking sector in Nigeria.

\subsection{Conclusion}

From the research findings, it is appropriate to assert that promotional activities are very necessary for the increased sales and to ensure higher profits and its proper implementation will ensure cost control/production and efficient marketing effort.

Promotional activities are communication tools that inform potential and current buyers of the existence price and place of purchase of goods and service. As Kolter rightly puts it, "it is not just enough to produce the right product, at the right price, but also, it is necessary to make it available at the right place for the target audience". It is against this background that they should be well understood, managed and evaluated effectively to maintain the already existing market share and also capture new market areas.

\subsection{Recommendations}

In modern business, companies objectively promote their products to create awareness, educate users of the usefulness and the benefits they could derive in the products. In view of this, the following recommendations have been made:

* Banking organization should employ more of promotional activities such as sales promotion, advertising and personal selling, to capture the market areas that are yet to be reached. This will check effectively the activities of those challenges who which to obtain their market share through the back door strategy.

* Banking organization should endevour to give their marketers more incentives as this will further motivate them and make them committed to their jobs, which will enable the organizations to get to the targeted market customers.

* The management of such organizations should try as much as possible to maintain a good relationship with its customers especially the distributors (who are closer to them) so as to earn their loyalty and build more support for the wide range of products of such organizations.

* These organizations should go into broader marketing planning concepts because of the increasing market opportunities. This will enhance their position as market leaders.

* There is need for a periodic review of promotional activities to ensure adequate communication link to the ultimate customers of the products.

* Managers of bank branches should not only emphasize promotion rather emphasis should be placed on what the company offers, how much it can satisfy its customers.

* There is also the need for marketing research and performance evaluation, to know the position of the products in the market. This helps the company to direct investments on deficient areas. However, because of high literacy level organization should concentrate more on personal selling more than any other promotional mix.

* Such multinational organization as in case of companies under investigation should improve on their social responsibilities and see it as a promotional mix.

* If profit is a substance of organization and promotional activities increase the sales which profit depend upon, therefore more money has to be apportioning for promotional activities in other to increase the sales more and profit margin to be larger.

* Once the promotional activities maintain the already capture market and increase them, then the organization should concentrate more on it in other to maintain their lead in the market.

\section{REFERENCES}

Aigbiremolen and Aigbiremolen. (2004). Marketing Banking Services in Nigeria. Lagos, The CIBN Press Limited.

Alford D. (2011). Nigerian Banking Reforms: Recent Actions and Future Prospects www.proshareng.com/articles/2268 extracted on 23rd of October 2011.

Allen L. (2004). A Critical Study of the Impact of Strategic Marketing in Nigerian Banking Industry", http://www.scribd.com/doc/16428438/Final-Project-Report-on-BankMarketing extracted on 11th December 2011.

Baker J. (1985). Marketing: An Introductory Text, London; Macmillan books.

Barile J. (2007). Standardization of International Marketing Strategy: Some Research Hypotheses. Journal of Marketing Vol. 5 (3).

Becker L., Chammard B., Hussein W., Kotsuji Y., Quagraine N. (2008). Nigeria Financial Services Cluster Analysis and Recommendation, The Microeconomics of Competitiveness: Firms. Clusters \& Economic Development. Vol, 12 (1).

Blue P. (1984). Marketing Management: A Strategy Planning Approach, London: McGraw-Hill, p. 188.

Charles L., Gareth J. (1998); Strategic Management Theory: An Integrated Approach, Houghton Mifflin 
Company, Boston, pp. 2-30.

Cohen H. (2008). Marketing Strategy-Performance Relationship: An investigation of the Empirical Link In Export Market Ventures, Journal of Marketing. Issue 56.

Deryk W. (1969); "Management Policies for Commercial banks", www.knowledgebank.com extracted on 24th of November, 2011.

Drucker P. (1999). Management Challenges for $21^{\text {st }}$ Century. New York, Harper Collins,..

Duro L. (1999). Strategic Marketing for Competitive Advantages, Business and Management, A Quarterly Publication of Michael Stevens and Associates, Vol. 2 (2), .

Ekerete P. (2005). Marketing of Financial Services, Pak. Economic and Social Review., XLIII, No. 2, p. 275.

Ikpefan, O. A. (2013). The impact of marketing of financial services in the Nigerian banking industry. Journal of Business Administration and Management Sciences Research Vol. 2(6)

Jigyasu P. (2006); The History of Nigerian Banking System, http://answers.yahoo.com/question/index extracted 30th, November, 2011.

Kin E. (2008). A Critical Analysis of the Services of the Nigerian Banking Systems, Unpublished B.Sc Degree of Banking and Finance, Covenant University, Ota, Ogun state.

Kotler P. and Armstrong G. (1987). Banking: An Introduction., New Jersey, Prentice-Hall Inc., Englewood Cliffs.

Kotler P. (1996). Marketing Management: Analysis, Planning, Implementation and Control. New Jersey .Prentice-Hall International,.

Lawrence J., and William G. (1988). Strategic Management and Business Policy. New York. McGraw-Hill Inc.

Lawrence G. (2001). The Coming of Age of Scanner Data Making Research, A Magazine of Management and Application, Winter.

Levine, R,. Loayza, N, and Beck, T, (2000). Financial intermediation and growth: Causality and causes. Journal of Monetary Economics Vol. 46 (31\}.

Mohan C., Kotler P. (2008). Marketing of Banking Services In Rural Areas, www.knowledgebank.com extracted on 5th October 2018.

Nzotta M. S. \& Okereke J. E. (2009). Financial Deepening and Economic Development of Nigeria: An Empirical Investigation, Africa Journal of Accounting, Economics, Finance and Banking Research Vol. $5(5)$.

Ogunsanya A. (2003); A Practical Guide to the Marketing of Financial Services. Lagos. Richmind Books limited,

Ojo O. (2005). Fundamental of Research Method 2nd edition.. Lagos. Standard Publications,

Okonkwo O. (2004); The Marketing of Financial Services in Nigeria, Aba. Esquire Press \&Books Co.

Okuonghae B. (2009). The Importance of Marketing In Banking Sector, Unpublished B.Sc. Degree of Banking and Finance, Covenant University, Ota, Ogun state.

Olujide O., Adeyemi S., Taiwo I., Adeoti J., Oribabor P., Adeyemi, K. andOlowe, R. (2004). Advances in management, Journal of Dept. Business. Administration. Vol. 4(1).

Onah J. (2009). Marketing and Nigeria's Economic Development, NIMARK Mark. Journal. Vol. 5(2).

Sobowale D. (1997). Developing Indigenous Marketing Strategy for Competitive Advantage. Journal Nigeria Institute of Management Vol. 33(3 \& 4).

Somoye R. (2008). The Performances of Commercial Banks in Post-Consolidation Period in Nigeria: An Empirical Review. European Journal of Economics and Financial Admin. Sci., Issue 14.

Uche C., and Ehikwe A. (2001). Globalization and the Marketing of Banking Services In Nigeria, World Services Congress held in Hong Kong, September 19-21.

Udoma A., and Olofin O. (2008). Financial Structure and Economic Growth in Nigeria: Macro Econometric Approach, Nigeria Journal of Security Finance., Issue 13.

Usman S. (2002). A Critical Overview of the Nigerian Financial Markets", A Paper Delivered at the National Workshop on the Development of the Nigeria Financial Market, held at Yar'adua Centre, Abuja, June 24th.

Ward S. (2004). "Marketing Financial Services", http://sbinfocanada.about.com/od/marketing/g/mrketin. htm extracted on 26thNovember, 2018.

Watkin T.,Ennew C., and Wright M. (1995). Marketing of Financial Services, Buttworth, Heinemann,

Worlu R., kehinde J., Adegbuyi O. (2007). Marketing: Principles and Applications, Port Harcourt . Macrowly Konsult,

Zeithamil V. (2000). Service Quality, Profitability and the Economic Worth of Customers: What We Know and What We Need to Learn. Journal of Academy of Marketing Sciences. Vol. 28(1): 